\title{
Influence of Cosmetics Vehicles on 4-Methylbenzylidene- Camphor's Skin Penetration, in vitro
}

\author{
Clarice Scliar Sasson ${ }^{1 *}$, Mayumi Eliza Sato ${ }^{1}$, Klézia da Silva Beletti ${ }^{2}$, Fabrício Cunha \\ Mota $^{2}$ and Angela Dakiw Piaceski ${ }^{2}$ \\ ${ }^{1}$ Universidade Federal do Paraná; Programa de Pós Graduação em Ciências Farmacêuticas; Departamento de \\ Farmácia; Av.Lothário Meissner, 632; Curitiba - PR - Brasil. ${ }^{2}$ O Boticário; Pesquisa e Inovação; Curitiba - PR - \\ Brasil.
}

\begin{abstract}
The aim of this work was to compare the skin penetration of 4-methylbenzylidene-camphor (4-MBC) in two vehicles, an oil-in-water $(O / W)$ emulsion and an alcoholic gel. The penetration of this UVB filter through these vehicles was determined in vitro (Franz cells) using pig ear skin. The 4-MBC permeated through the skin both with the emulsion $\mathrm{o} / \mathrm{w}$ as the alcoholic gel. However, with the alcoholic gel, $5 \mathrm{~h}$ after application of the product, the 4-MBC was found in the receptor fluid, while with the emulsion o/w, 24 h after it was detected. In both vehicles, the 4-MBC was present in the viable epidermis, dermis but most part of it, was found in the stratum corneum, being more remarkable for alcoholic gel. The right choice of the vehicle could decrease the potential toxicological risk and increase the efficacy of sunscreens products.
\end{abstract}

Key words: 4-Methylbenzylidene-camphor, sunscreens, penetration, vehicles

\section{INTRODUCTION}

On certain aspects, sun exhibition can be beneficial. However, it can have serious consequences on skin such as actinic ageing or something worse like skin cancers of different types according to the proportion and exhibition length (Patel et al., 1992; Horiot et al., 1995; Berset et al., 1996). The increased awareness of protection against skin cancer has led to a worldwide rise in the usage of topically applied chemical sunscreen agents (Gasparro et al., 1998; Mac Lennan et al., 1992). Despite extensive usage of sunscreens products, so far moderate attention has been paid to the potential permeation of the UV filters through skin and the possible subsequent effect (Hayden et al., 1994). The desirable site of action of the UV filters is restricted to the skin surface or to the uppermost part of the stratum corneum. However, it has been demonstrated that penetration into skin, permeation through skin and retention of UV filters in the skin from topical products can differ significantly between formulations used (Chatelain et al., 2003).

Jiang et al., (1999) found that diffusion of UV filters across the epidermis varied significantly with formulation type. The 4-Methylbenzylidenecamphor (4-MBC) is a UVB filter with high wavelength absorption, is an organic camphor derivative and suitable for use in all major types of sunscreen products (Tassopoulos et al., 2004). However, nowadays, there are many articles informing about the estogenic activity of 4-

\footnotetext{
*Author for correspondence: clarice@ boticario.com.br
} 
methylbenzylidene-camphor and also about strong anti-osteoporotic effects after chronic application (Seidlova-Wuttke et al., 2006). Additionally, $4 \mathrm{MBC}$ can be re-absorbed through the skin. Durrer et al., (2005) observed that the 4-MBC altered steady-state levels of mRNAs encoding for ER alpha, ER beta, progesterone receptor (PR), IGF-I, androgen receptor, determined by real-time RTPCR in uterus of 12-week-old offspring. Hamann et al., (2006) observed that 4-MBC was a potent inhibitor of the pituitary-thyroid-axis due to the fact that TSH serum levels were significantly elevated and the weight of the thyroid glands that was remarkably increased. Beside these facts, the 4-MBC may be a potentially harmful substance for water-dwelling animals when present in the environment at micromolar concentrations (Klann et al., 2005). The present study examined the influence of two different cosmetic vehicles in cutaneous permeation of 4-Methylbenzylidenecamphor by in vitro experiment using Franz cells.

\section{MATERIAL AND METHODS}

\section{Chemicals and Formulation}

4-Methylbenzylidene-camphor was obtained from Hoffman-La Roche Ltd (Basel, Switzerland). Potassium phosphate-monobasic and sodium hydroxide from Merck (Germany), oleth-20 from Croda, acetic acid and orto-phosphoric acid GR from Merck, methanol and isopropanol HPLC grade from Merck. Adults albino pig full-thickness ear skin, free from subcutaneous fat and other extraneous tissue, was obtained from authorized slaughterhouse by the Brazilian Agriculture Ministry for human consumption and in order to store it at the required temperature $\left(-18^{\circ} \mathrm{C}\right)$, it was frozen. Two sunscreen formulations were prepared, both containing 4\% of 4-MBC. Formulation 1, was an $\mathrm{O} / \mathrm{W}$ emulsion composed by water, disodium EDTA, triethanolamine, propylene glycol, potassium cethyl phosphate, acrylates/C10-30 alkyl acrylate crosspolymer in the water phase and tocopheryl acetate, BHT, dibutyl adipate, cetyl alcohol, stearyl alcohol and preservatives in the oil phase. Formulation 2 was an alcoholic gel composed by alcohol, hydroxypropylcellulose, tocopheryl acetate, BHT, dibutyl adipate, glycerin, acrylates/C10-30 alkyl acrylate crosspolymer and fragrance.

\section{In vitro Penetration}

Pig full-thickness skin was mounted in a conventional Franz diffusion cells (Microette PlusHanson Research ${ }^{\circledR}$ ) with a receptor volume of 7.0 $\mathrm{ml}$. The receptor compartment $(\mathrm{n}=6)$ was filled with a solution containing buffer phosphate $\mathrm{pH} 7.4$ (40\%), alcohol $(50 \%)$ and oleth-20 $(10 \%)$ at $32^{\circ} \mathrm{C}$ and stirred with a magnetic bar at $300 \mathrm{rpm}$. The cell allowed $2.01 \mathrm{~cm}^{2}$ skin to be exposed to the formulation at room temperature $\left(22^{\circ} \mathrm{C}\right)$ and $20 \pm$ $0.2 \mathrm{mg} / \mathrm{cm}^{2}$ sunscreen product was applied to the skin for a period of $24 \mathrm{~h}$, keeping one cell as the control. In t0, 5, 8 and $24 \mathrm{~h}, 1.5 \mathrm{ml}$ of receptor fluid was removed from the cell and analyzed (assessment of possible permeation of 4-MBC). The 4-MBC was readily soluble in the receptor fluid. In $8 \mathrm{~h}$ of experiment, the skin surface was washed with $3 \mathrm{ml}$ of receptor fluid and quantified by HPLC. At $24 \mathrm{~h}$, the skin was removed from the cells, stratum corneum (SC) was stripped with \pm 40 adhesive tapes $\left(3 \mathrm{M}^{\circledR}\right)$ that became in contact with methanol for $30 \mathrm{~min}$ in ultrasound to break the cells. After that, it was evaporated and the active component was re-solubilized with $4 \mathrm{ml}$ of the fluid receptor and quantified by HPLC. The epidermis and dermis were cut in little pieces and put in contact with methanol for $30 \mathrm{~min}$ in the ultrasound and the same procedure described for the SC was made for the epidermis (without SC) + dermis. The total recovered $4-\mathrm{MBC}$ was $85-90 \%$.

\section{HPLC Analysis}

A method was previously developed and validated to quantify the 4-MBC by HPLC (Agilent RC). A $250 \times 4.6 \mathrm{~mm}$ Ultrasphere ODS C18, HD, 5- $\mu \mathrm{m}$ column (Beckman Coulter) was used at a constant temperature of $21^{\circ} \mathrm{C}$. The flow rate of the mobile phase- methanol/water/ acetic acid (85/15/0.5,v.v) was $1.5 \mathrm{ml} / \mathrm{min}$ and the detection wave-length was $388 \mathrm{~nm}$. Sample was injected via a $20-\mu \mathrm{l}$ loop. Calibration curves were obtained from least squares linear regression established from 15 calibration points. The analytical method was properly developed and validated for the steps of specificity, linearity, precision, accuracy and intermediary precision in accordance with the RE 899/ 2003 (BRASIL.,2003).

\section{Statistical analysis}

The results were analyzed by ANOVA followed by post-hoc from Tukey and values of $(p<0.05)$ were considered statistically different. 


\section{RESULTS}

The in vitro penetration data in the receptor fluid are shown in Fig. 1. The 4-MBC was detected in the receptor fluid. The alcoholic gel permeated through the skin $5 \mathrm{~h}$ after the product application and with the o/w emulsion, only after $24 \mathrm{~h}$. At the end of experiment, 4-MBC was detected in the viable epidermis and dermis and the amount was comparable in both the vehicles. By using the alcoholic gel, the retention into stratum corneum was more pronounced; however, the amount detected at the skin surface after $8 \mathrm{~h}$ application product was more pronounced with the $\mathrm{o} / \mathrm{w}$ emulsion (Table 1). The analytical method was considered specific, linear, precise and accurate, being therefore validated for these steps.

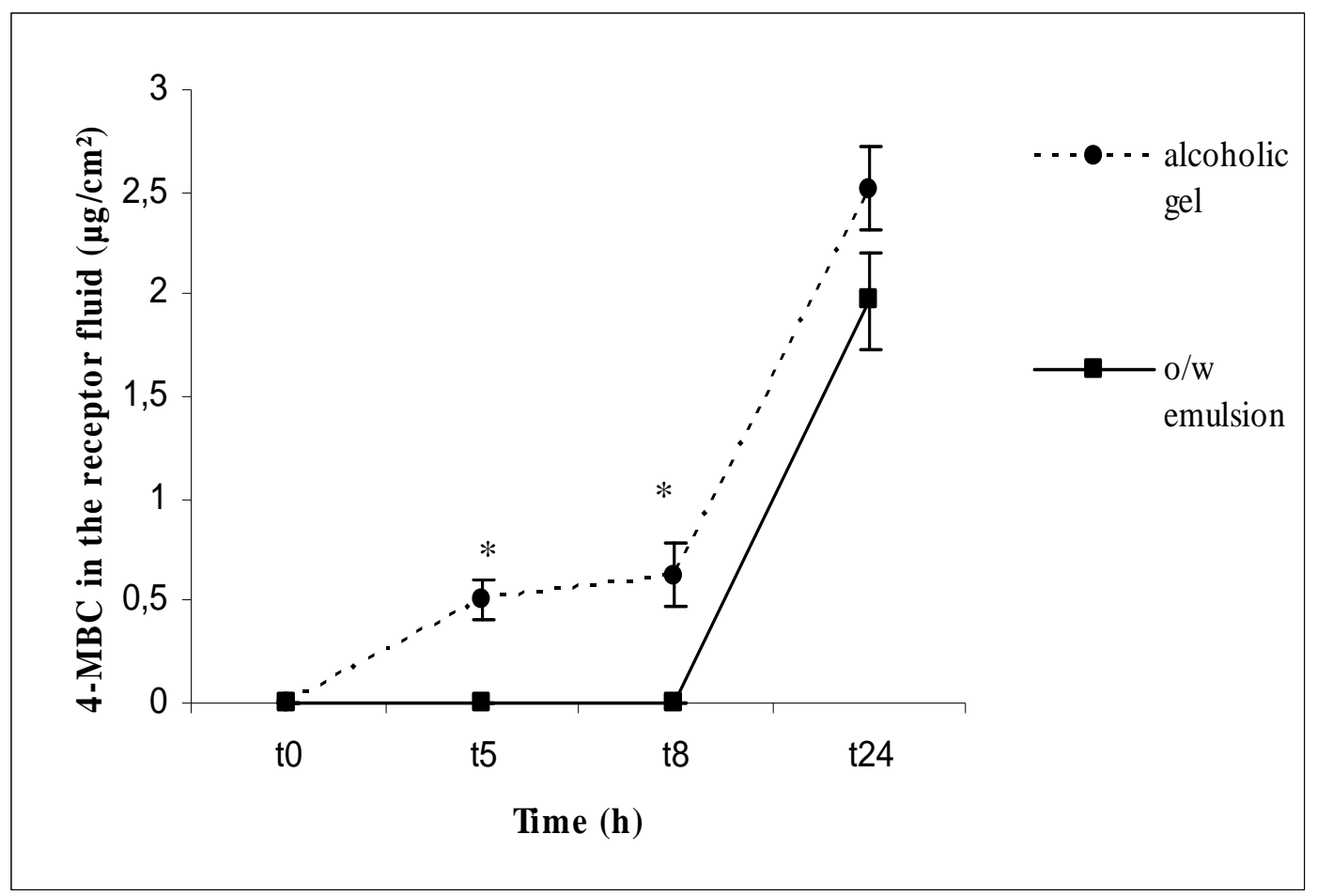

Figure 1 - Concentration profile of 4-MBC present in the receptor fluid after application of the alcoholic gel and the o/w emulsion. The amount of 4-MBC in the receptor fluid, expressed in $\mu \mathrm{g} / \mathrm{cm}^{2}$ is represented in the graphic above. (mean $\pm \mathrm{SD}, \mathrm{n}=5$ ), $* \mathrm{p}<$ 0,05 in contrast with $\mathrm{t} 5 \mathrm{~h}$ and $\mathrm{t} 8 \mathrm{~h}$ of $\mathrm{o} / \mathrm{w}$ emulsion.

Table 1- Penetration in vitro of 4-MBC $24 \mathrm{~h}$ after product application; expressed as ' $\%$ '; mean, $\mathrm{n}=5$ ( $\%$ of the applied dose).

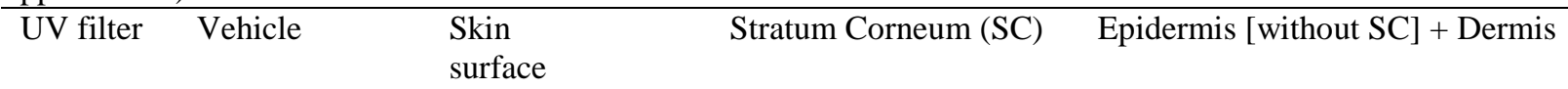

\begin{tabular}{lllll}
\hline 4-MBC & Alcoholic gel & $75,98( \pm 4,06)$ & $7,208( \pm 0,97) *$ & $2,53( \pm 0,45)$ \\
& O/W emulsion & $80,125( \pm 6,19)^{* *}$ & $4,522( \pm 0,72)$ & $2,9225( \pm 0,5)$
\end{tabular}

\footnotetext{
* $\mathrm{p}<0,05$ in contrast with (SC) of $\mathrm{O} / \mathrm{W}$ emulsion

$* * \mathrm{p}<0,05$ in contrast with skin surface of alcoholic gel
} 


\section{DISCUSSION}

The present work confirmed that the penetration of 4-MBC was vehicle-dependent and in both vehicles, it was detected in the viable epidermis and dermis. The highest amount was detected in the stratum corneum and smaller amounts in the hydrophilic epidermis and dermis which could be justify by its lipophilic characteristics (Jiang et al., 1999). The amount of 4-MBC detected in the receptor fluid after vehicles application (Fig. 1) showed that with the alcoholic gel, $5 \mathrm{~h}$ after product application, the 4-MBC could be detected and the amount increased with the increase of time. With the $\mathrm{O} / \mathrm{W}$ emulsion, however, only $24 \mathrm{~h}$ after product application, the 4-MBC was detected in the receptor fluid. The difference between the vehicles probably could be explained by the fact that in the alcoholic gel, the alcohol present in the formulation volatilized during the stratum corneum diffusion, a super- saturated system was created and with that, the liberation of 4-MBC was more efficient (Alberti et al., 2001). This was comprehensive, considering the observations present in literature about the ethanol effect on drug absorption across the skin. The difference in the amount retained in the stratum corneum and in the skin surface between the alcoholic gel and the $\mathrm{O} / \mathrm{W}$ emulsion can be seen in the Table 1 . The amount of 4-MBC in the stratum corneum using the alcoholic gel, was higher than using the $\mathrm{O} / \mathrm{W}$ emulsion and the opposite happened with the skin surface. This indicated that the vehicle provided an efficient partitioning of 4-MBC into stratum corneum. The increased thermodynamic activity of the 4-MBC could explain the efficient delivery to the stratum corneum. Walters et al.(1997) mentioned that it was well established that one of the principles of direct force for the diffusion across the skin was the thermodynamic activity of the active in the donor vehicle and this activity was reflected by the concentration of the active in the donor vehicle due to its saturation solubility in the media. More close was the saturation amount, the higher was the thermodynamic activity and the tendency for the vehicle release. A study of different kinds of sunscreens vehicles could be effective in order to improve the formulations of sun protection products.

\section{ACKNOWLEDGMENTS}

We are thankful to Programa de Pós Graduação em Ciências Farmacêuticas da UFPR and $\mathrm{O}$ Boticário-Pesquisa e Inovação for having provided financial and technical support for this project.

\section{RESUMO}

O objetivo deste estudo foi avaliar a influência de diferentes veículos cosméticos na permeação cutânea da 4-metilbenzilideno cânfora através de experimento in vitro utilizando células de difusão de Franz. Os veículos avaliados foram um gel alcoólico e uma emulsão não iônica O/A. Durante o experimento, foi doseada a presença da 4-MBC no fluido receptor em $\mu \mathrm{g} / \mathrm{cm}^{2}$, desde o tempo $0 \mathrm{~h}$ até $24 \mathrm{~h}$ após a aplicação dos veículos, bem como sua concentração na superfície cutânea, estrato córneo e [epiderme sem estrato córneo + derme]. No estudo realizado com o gel alcoólico, a partir de $5 \mathrm{~h}$ após o início do experimento, já foi detectada a presença da 4-MBC no fluido receptor, ao passo que, utilizando a emulsão O/A, a 4-MBC foi detectada apenas após $24 \mathrm{~h}$. Em ambos os veículos a 4-MBC estava presente na [epiderme sem estrato córneo + derme] não havendo diferença estatística entre eles. A maior concentração de 4-MBC foi detectada na superfície cutânea, estando em maior quantidade quando utilizada a emulsão O/A como veículo. Já no estrato córneo, a concentração de 4-MBC foi maior na utilização do gel alcoólico. Analisando os resultados obtidos, observa-se que a penetração e a retenção cutânea da 4-metilbenzilideno cânfora são dependentes da natureza do veículo utilizado.

\section{REFERENCES}

Berset, G.; Gonzenbach, H.; Christ, R.; Martin, R.; Deflandre, A.; Mascotto, R.E.; Jolley, J.D.; Lowell, W. ; Pelzer, R. ; Stiehm, T. (1996), Proposed protocol for determination of photostability. Part I : Cosmetics UV filters. Int J. Cosmet., 18, 167-177.

BRASIL. Resolução RE n.899 de 29 maio de 2003. O adjunto da diretoria colegiada da Agência Nacional de Vigilância Sanitária estabelece o Guia Para Validação de Métodos Analíticos e Bioanalíticos. Diário Oficial da União, Brasília, n.104, 2 jun. 2003. Seção I, p.56. 
Chatelain, E.; Gabard,B.; Surber,C. (2003), Skin penetration and sun protection factor of five UV filters: Effect of the vehicle. Skin Pharmacol Appl Skin Physiol., 16, 28-35.

Durrer, S., Maerkel, K., Schlumpf, M.,Lichtensteiger, W.(2005), Estrogen target gene regulation and coactivator expression in rat uterus after developmental exposureto the UV filter 4methylbenzylidene camphor. Endocrinology., 146, 2130-2139.

Gasparro, F.P.; Mitchnik, M.; Nash, J.F. (1998), A review of sunscreen safety and effecacy. Photochem Photobiol., 68, 243-256.

Hamann,H.; Schmutzler,P.; Kirschmeyer,H.; Jarry,H; Köhrle,J.(2006), 4-Methylbenzylidene-camphor (4MBC) causes pituitary effects comparable to hypothyroidism. Endocrine Abstracts., 11, OC60.

Hayden, C.G.J.; Benson, H.A.E.; Roberts, M.S.(1994), Sunscreens : Toxicological aspects : in Roberts, M.S, Walters ,K.A.(eds) : Dermal absorption and toxicity assessment . Dekker, New York, pp. 537-599.

Horiot, T.; Miyauchi, H.; Sindhva Nanda, J. ; Soh, H.; Kurokava, L. ; Asada, Y. (1995), The effect of ultraviolet (UVB and UVA) radiation on the expression of epidermal keratins. Br. J. Dermatol., 28, 10-15

Jiang, R.; Roberts, M.S.; Collins, D.M.; Benson, H.A.E. (1999), Absorption of sunscreens across human skin : An evaluation of commercial products for children and adults. Br J. Clin Pharmacol., 48, 635-640.
Klann,A.; Levy,G.; Lutz,I.; Muller,C.; Klods,W.; Hildebrandt, JP.(2005), Estrogen-like effects of ultraviolet screen 3-(40methylbenzylidene)-camphor (Eusolex 6300) on cell proliferation and gene induction in mammalian and amphibian cells. Environ Res., 97, 274-281

Mac Lennan, R.; Green, A.L.; Mc Leod, G.R.C.; Martin, N.G. (1992), Increasing inicidence of cutaneous melanoma in Queensland, Australia. $J$. Natl Cancer Inst., 84, 1427-1432.

Patel, N.P.; Highton, A.; Moy, R.L. (1992), Properties of topical sunscreens formulation: a review. $J$. Dermatol Surg. Oncol., 18, 316-320.

Seidlova-Wuttke,D.; Jarry,H.; $\quad$ Christoffel,J.; Rimoldi,G.; Wuttke,W, Comparison of effects of estradiol (E2) with those of octylmethoxycinnamate (OMC) and 4-methylbenzylidene camphor (4-MBC) 2 filters of UV light - on several uterine, vaginal and bone parameters. Toxicol Appl Pharmacol., 210, 146254.

Tassopoulos, T.; Vuong, H.; Pellanda, C.; Imanidis, G.; Figueiredo, V.; Rufli, T.; Smith, E.W.; Surber, C. (2004), Topical bioavailability of sunscreen agents in stratum corneum : effect of vehicle and time. Paper presented at $9^{\text {th }}$ International Conference of Pespectives in Percutaneous Penetration, 13-17 April, France. 